\title{
Recurrent Pregnancy Loss and Thrombophilia
}

\author{
Maristella D’Uva ${ }^{a}$, Pierpaolo Di Micco ${ }^{\mathrm{b}, \mathrm{c}}$, Ida Strina ${ }^{\mathrm{a}}$, Giuseppe De Placido ${ }^{\mathrm{a}}$
}

\begin{abstract}
Emerging data seem to be available also on the role of active thromboprophylaxis with heparin and pregnancy outcome. In the last decades we found many data concerning the association between a hypercoagulable state and its causes and adverse pregnancy outcome, in particular recurrent pregnancy loss (RPL). First studies which focused on the association between thrombophilia and RPL underlined the role of reduced clotting inhibitors and RPL, and subsequent studies underlined a pathogenetic role of gene variant associated to hypercoagulable state in the occurrence of RPL. On the other hand, acquired thrombophilic abnormalities as antiphipsholipid syndrome are a well known cause of RPL and should be considered for a screening. These data are relevant because recent studies suggested a role of an extensive thromprophilaxis in women with RPL that should be addressed only in case of known thrombophilia and high risk of venous thromboembolism.
\end{abstract}

Keywords: Thrombophilia; Recurrent pregnancy loss; Factor V Leiden; Hyperhomocysteinemia; Antiphospholipid antibodies; PAI $4 \mathrm{G} \backslash 4 \mathrm{G}$

\section{Introduction}

Recurrent pregnancy loss (RPL) represents a major health problem with two to three or more losses in up to $5 \%$ of women of reproductive age and is actually one of the most

\footnotetext{
Manuscript accepted for publication February 5, 2010

${ }^{\mathrm{a}}$ Department of Obstetrics and Gynecology and Human Reproduction, 'Federico II' University of Naples, Naples, Italy

b Internal Medicine Division, Buonconsiglio Fatebenefratelli Hospital of Naples, Naples, Italy

${ }^{\mathrm{c} C o r r e s p o n d i n g ~ a u t h o r: ~ I n t e r n a l ~ M e d i c i n e ~ D i v i s i o n, ~ B u o n c o n s i g l i o ~}$

Fatebenefratelli Hospital of Naples, Via San Giacomo dei Capri 69,

Naples, Italy. Email: pdimicco@libero.it
}

doi:10.4021/jocmr2010.02.260w common causes of female sterility [1]. Several reports identify inherited predisposition to thrombophilia as one of the main causes of RPL in particular if several diseases potentially responsible of RPL have been already excluded such as endocrine diseases (such as ovarian dysfunction, anovulation, hypopituitarism and diabetes), uterine malformation, genetic alterations (for example, chromosomal aberrations), inflammatory diseases (in particular systemic lupus erythematosus) and infectious diseases [2-5]. From a pathological point of view, women affected by thrombophilia show during their pregnancy a hypercoagulable state that is already increased during pregnancy, which may impair placental flow and then its function and fetal growth and may predispose to develop venous thrombosis [6].

During pregnancy, in fact, we may observe many changes in the haemostatic balance with a trend toward thrombophilia in order to be prompt for the haemostatic challenge of delivery [2, 6-7]. Thus, pregnancy is a condition associated to thrombophilia per se and for this reason it is associated with the increase of several clotting factors (namely factor VIII, vWF, fibrinogen and factor VII) [7]. Moreover, also other markers of a hypercoagulable state are increased during pregnancy, such as D-dimer and/or prothrombin fragment $1+2[7,8]$. For this reason we may observe episodes of venous thromboembolism (VTE) during pregnancy [9]. Moreover, women carrying further thrombotic risk factors such as inherited thrombophilia show an additionally increased risk of thrombotic events during pregnancy such as venous thromboembolism and/or abortion [10].

VTE and pulmonary embolism (PE), in fact, continue to be a leading cause of maternal death during pregnancy or postpartum and may cause significant morbidity of pregnant women.

The aim of the review is to focus fundamental clinical aspect of thrombophilias in the occurrence of RPL.

\section{Inherited Thrombophilia and Pregnancy Loss}

Thrombophilia has been identified as one of the main causes of RPL with a percentage of until $40 \%$, in particular early RPL [11]. Although several studies on this topic are available 
in the literature to confirm this trend, rates of thrombophilia seem to differ from study to study because of different inclusion criteria and different ethnic backgrounds of the selected patients [12]. In this clinical setting we may differentiate inherited thrombophilia, acquired thrombophilia and combined thrombophilia [13-14].

Inherited thrombophilia may be due to deficiency of clotting inhibitors or to gene variants leading to a hypercoagulable tendency. Gene variants frequently associated with RPL are prothrombin A20210G and/or factor V Leiden. Prothrombin A20210G has been identified as a risk factor for pregnancy loss in several studies and has been associated mainly to early RPL [15-19]. On the other hand, factor $\mathrm{V}$ Leiden, which is responsible for more than $75 \%$ of inherited activated protein $\mathrm{C}$ resistance, is the more common inherited thrombotic risk factor associated to RPL [20-22]. In particular, a case control study by Ridker et al. has reported an increased prevalence of FVL in women with RPL, while other studies revealed a strong relationship between FVL and early RPL [23]. FVL has been identified as a risk factor also for late RPL [24]. Also deficiency of clotting inhibitors, such as protein $\mathrm{S}$, protein $\mathrm{C}$ and/or antithrombin, has been clearly associated to RPL since $1996[25,26]$.

In the latest years an emerging role has been suggested and underlined also for the PAI-1 4G $\backslash 5 \mathrm{G}$ gene variant that may be associated to hypofibrinolysis and so to hypercogulable state. Several reports underlined the association between 4G $\backslash 4 \mathrm{G}$ genotype of PAI-1 and RPL $[27,28]$ and this association seems to be relevant if anamnestic VTE is also present [29]. Yet more detailed data on large based population are needed in next years.

\section{Hyperhomocysteinemia}

A pathogenetic role of hyperhomocysteinemia (HHCY) in RPL has been underlined by several reports on this topic, but data available in the literature are actually not univocal. Several authors reported increasing evidences for the relationship between HHCY, methylenetetrahydrofolate reductase gene polymorphism C677T (MTHFR C677T) and RPL, in particular early RPL [25,30-32]. On the other hand, further authors found a negative association between HHCY and early RPL [33-35].

\section{Acquired Thrombophilia}

Several authors underlined the role of the antiphospholipid syndrome (APS) in the pathophysiology of RPL [36-48]. To confirm this point, actually adverse pregnancy outcome is considered as one of the diagnostic criteria of APS (Table 1) according to the guidelines of the International Society of Thrombosis and Haemostasis and the American Rheumatology Association [49, 50]. During APS, a large variety of autoantibodies also toward clotting factors, such as factor XII, has been found $[51,52]$. However, a clear explanation of all involved processes on the roles of antiphospholipid antibodies and of autoantibodies toward clotting factors is still matter of discussion.

On the other hand, new evidence seems to be available for the role of increased maternal plasma levels of clotting factor VIII and the risk of RPL [53]. Furthermore, acquired activated protein $\mathrm{C}$ resistance, which is not associated with

Table 1. Diagnostic Criteria to Detect Antiphospholipid Syndrome

\author{
Clinical Criteria \\ (Vascular thrombosis of arterial and/or venous vessels \\ in any tissue or organ) \\ Pregnancy morbidity
}

Laboratory Criteria

One or more unexplained deaths of a morphologically normal fetus at or beyond the 10th week of gestation

\begin{abstract}
One or more unexplained deaths of a morphologically normal neonate before the 34 th week of gestation because of eclampsia or severe eclampsia or placental insufficiency
\end{abstract}

Three or more unexplained consecutive spontaneous abortions before the 10th week of gestation

\begin{abstract}
Lupus anticoagulant present in plasma, on two or more occasions at least 12 weeks apart, detected according to the International Society of Thrombosis and Haemostasis (ISTH)
\end{abstract}

Anticardiolipin antibody (aCL) of IgG and/or IgM isotype in serum or in plasma present in medium or high titer on two or more occasions at least 12 weeks apart

Anti- $\beta_{2}$ glycoprotein-I antibody of IgG and/or IgM isotype in serum or in plasma present on two or more occasion at least 12 weeks apart

For more details we suggest to consult Miyakis S, et al. J Thromb Haemost. 2006;4:295-306 [50]. 
the presence of FVL, has been described in several women with RPL, but also in this case, not all involved mechanisms are known [54].

\section{Combined Thrombophilia}

Combined thrombophilia, namely inherited thrombophilia associated with acquired thrombophilia or more than one inherited thrombophilic defect, has also been identified as a cause of RPL, but its real frequency is not clear. Several studies in the latest years identified combined thrombophilic defects in women with RPL both early RPL and late RPL $[10,28,55]$.

\section{Conclusions}

Active surveillance of women referred to gynecological centers for RPL should be supported by thrombophilia screening. This approach may be helpful to fight this major health problem that involves up to $5 \%$ of women of reproductive age by an appropriate antithrombotic treatment. Inherited and/or acquired thrombophilia has been diagnosed in 50\% to $65 \%$ of women with history of unexplained RPL and in nearly $20 \%$ of women with RPL with age of more than 35 years [56].

This gynecological and clinical aspect may be considered in particular if anamnesis reveals the presence of personal andlor familial trend to develop thrombotic disorders in particular VTE. So an appropriate clinical evaluation focused on diagnosis and therapy of RPL should also consider thrombophilic defects.

\section{References}

1. Sarig G, Younis JS, Hoffman R, Lanir N, Blumenfeld Z, Brenner B. Thrombophilia is common in women with idiopathic pregnancy loss and is associated with late pregnancy wastage. Fertil Steril 2002;77(2):342-347.

2. Eldor A. Thrombophilia, thrombosis and pregnancy. Thromb Haemost 2001;86(1):104-111.

3. Carp H, Salomon O, Seidman D, Dardik R, Rosenberg N, Inbal A. Prevalence of genetic markers for thrombophilia in recurrent pregnancy loss. Hum Reprod 2002;17(6):1633-1637.

4. Prandoni P, Tormene D, Simioni P, Girolami A. Venous thromboembolism, fetal loss and preeclampsia in pregnant women with congenital thrombophilia. Clin Lab 2001;47(3-4):155-159.

5. Di Micco P, D'Uva M, Strina I, De Placido G, Di Fiore R, Quaranta S, Castaldo G. Recurrent pregnancy loss and thrombophilia. Clin Lab 2007;53(5-6):309-314.
6. Abbate R, Lenti M, Fatini C, Gazzini A, Lapini I, Fedi S. L'ipercoagulabilità gravidica e puerperale. Haematologica 2003;88 (Suppl.7):1-2 [Italian]

7. Hathaway WE and Goodnight SH Jr. Thrombosis in pregnancy. In: Disorders of hemostasis and thrombosis. A clinical guide (Eds.) Hathaway WE, Goodnight HS Jr. New York: McGraw-Hill; 1993:430-6

8. de Boer K, ten Cate JW, Sturk A, Borm JJ, Treffers PE. Enhanced thrombin generation in normal and hypertensive pregnancy. Am J Obstet Gynecol 1989;160(1):95100.

9. Colman-Brochu S. Deep vein thrombosis in pregnancy. MCN Am J Matern Child Nurs 2004;29(3):186-192.

10. Robertson L, Wu O, Langhorne P, Twaddle S, Clark P, Lowe GD, Walker ID, et al. Thrombophilia in pregnancy: a systematic review. Br J Haematol 2006;132(2):171196.

11. Brenner B, Sarig G, Weiner Z, Younis J, Blumenfeld Z, Lanir N. Thrombophilic polymorphisms are common in women with fetal loss without apparent cause. Thromb Haemost 1999;82(1):6-9.

12. D’Uva M, Di Micco P, Strina I, Ranieri A, Alviggi C, Mollo A, Fabozzi F, et al. Etiology of hypercoagulable state in women with recurrent fetal loss without other causes of miscarriage from Southern Italy: new clinical target for antithrombotic therapy. Biologics 2008;2(4):897-902.

13. Martinelli I. Risk factors in venous thromboembolism. Thromb Haemost 2001;86(1):395-403.

14. Franchini M, Veneri D. Inherited thrombophilia: an update. Clin Lab 2005;51(7-8):357-365.

15. Pickering W, Marriott K, Regan L. G20210A prothrombin gene mutation: prevalence in a recurrent miscarriage population. Clin Appl Thromb Hemost 2001;7(1):25-28.

16. Pihusch R, Buchholz T, Lohse P, Rubsamen H, Rogenhofer N, Hasbargen U, Hiller E, et al. Thrombophilic gene mutations and recurrent spontaneous abortion: prothrombin mutation increases the risk in the first trimester. Am J Reprod Immunol 2001;46(2):124-131.

17. Finan RR, Tamim H, Ameen G, Sharida HE, Rashid M, Almawi WY. Prevalence of factor V G1691A (factor V-Leiden) and prothrombin G20210A gene mutations in a recurrent miscarriage population. Am J Hematol 2002;71(4):300-305.

18. Reznikoff-Etievan MF, Cayol V, Carbonne B, Robert A, Coulet F, Milliez J. Factor V Leiden and G20210A prothrombin mutations are risk factors for very early recurrent miscarriage. BJOG 2001;108(12):1251-1254.

19. Martinelli I, Taioli E, Cetin I, Marinoni A, Gerosa S, Villa MV, Bozzo M, et al. Mutations in coagulation factors in women with unexplained late fetal loss. N Engl J Med 2000;343(14):1015-1018.

20. Rai R, Shlebak A, Cohen H, Backos M, Holmes Z, Marriott K, Regan L. Factor V Leiden and acquired activated 
protein C resistance among 1000 women with recurrent miscarriage. Hum Reprod 2001;16(5):961-965.

21. Grandone E, Margaglione M, Colaizzo D, d'Addedda M, Cappucci G, Vecchione G, Scianname N, et al. Factor V Leiden is associated with repeated and recurrent unexplained fetal losses. Thromb Haemost 1997;77(5):822824.

22. Hatzis T, Cardamakis E, Drivalas E, Makatsoris K, Bevan D, Pantos C, Malliopoulou V, et al. Increased resistance to activated protein $\mathrm{C}$ and factor $\mathrm{V}$ Leiden in recurrent abortions. Review of other hypercoagulability factors. Eur J Contracept Reprod Health Care 1999;4(3):135-144.

23. Ridker PM, Miletich JP, Buring JE, Ariyo AA, Price DT, Manson JE, Hill JA. Factor V Leiden mutation as a risk factor for recurrent pregnancy loss. Ann Intern Med 1998;128(12 Pt 1):1000-1003.

24. Pabinger I, Nemes L, Rintelen C, Koder S, Lechler E, Loreth RM, Kyrle PA, et al. Pregnancy-associated risk for venous thromboembolism and pregnancy outcome in women homozygous for factor V Leiden. Hematol J 2000;1(1):37-41.

25. Sanson BJ, Friederich PW, Simioni P, Zanardi S, Hilsman MV, Girolami A, ten Cate JW, et al. The risk of abortion and stillbirth in antithrombin-, protein $\mathrm{C}$-, and protein S-deficient women. Thromb Haemost 1996;75(3):387-388.

26. ten Kate MK, van der Meer J. Protein S deficiency: a clinical perspective. Haemophilia 2008;14(6):12221228.

27. Goodman CS, Coulam CB, Jeyendran RS, Acosta VA, Roussev R. Which thrombophilic gene mutations are risk factors for recurrent pregnancy loss? Am J Reprod Immunol 2006;56(4):230-236.

28. Coulam CB, Jeyendran RS, Fishel LA, Roussev R. Multiple thrombophilic gene mutations rather than specific gene mutations are risk factors for recurrent miscarriage. Am J Reprod Immunol 2006;55(5):360-368.

29. Coulam CB, Wallis D, Weinstein J, DasGupta DS, Jeyendran RS. Comparison of thrombophilic gene mutations among patients experiencing recurrent miscarriage and deep vein thrombosis. Am J Reprod Immunol 2008;60(5):426-431.

30. Fatini C, Gensini F, Battaglini B, Prisco D, Cellai AP, Fedi S, Marcucci R, et al. Angiotensin-converting enzyme DD genotype, angiotensin type 1 receptor $\mathrm{CC}$ genotype, and hyperhomocysteinemia increase first-trimester fetal-loss susceptibility. Blood Coagul Fibrinolysis 2000;11(7):657-662.

31. Lissak A, Sharon A, Fruchter O, Kassel A, Sanderovitz J, Abramovici H. Polymorphism for mutation of cytosine to thymine at location 677 in the methylenetetrahydrofolate reductase gene is associated with recurrent early fetal loss. Am J Obstet Gynecol 1999;181(1):126-
130.

32. Nelen WL, van der Molen EF, Blom HJ, Heil SG, Steegers EA, Eskes TK. Recurrent early pregnancy loss and genetic-related disturbances in folate and homocysteine metabolism. Br J Hosp Med 1997;58(10):511-513.

33. Wouters MG, Boers GH, Blom HJ, Trijbels FJ, Thomas CM, Borm GF, Steegers-Theunissen RP, et al. Hyperhomocysteinemia: a risk factor in women with unexplained recurrent early pregnancy loss. Fertil Steril 1993;60(5):820-825.

34. Makino A, Nakanishi T, Sugiura-Ogasawara M, Ozaki Y, Suzumori N, Suzumori K. No association of C677T methylenetetrahydrofolate reductase and an endothelial nitric oxide synthase polymorphism with recurrent pregnancy loss. Am J Reprod Immunol 2004;52(1):60-66.

35. Nadir Y, Hoffman R, Brenner B. Association of homocysteine, vitamin B12, folic acid, and MTHFR C677T in patients with a thrombotic event or recurrent fetal loss. Ann Hematol 2007;86(1):35-40.

36. Noble LS, Kutteh WH, Lashey N, Franklin RD, Herrada J. Antiphospholipid antibodies associated with recurrent pregnancy loss: prospective, multicenter, controlled pilot study comparing treatment with low-molecularweight heparin versus unfractionated heparin. Fertil Steril 2005;83(3):684-690.

37. Infante-Rivard C, David M, Gauthier R, Rivard GE. Lupus anticoagulants, anticardiolipin antibodies, and fetal loss. A case-control study. N Engl J Med 1991;325(15):1063-1066.

38. Higashino M, Takakuwa K, Arakawa M, Tamura M, Yasuda M, Tanaka K. Anti-cardiolipin antibody and anti-cardiolipin beta-2-glycoprotein I antibody in patients with recurrent fetal miscarriage. J Perinat Med 1998;26(5):384-389.

39. Chakrabarti S, Bhunia C, Bhattacharya DK. The prevalence of antiphospholipid antibodies in cases of recurrent pregnancy loss. J Assoc Physicians India 1999;47(5):496-498.

40. Das I, Vasishta K, Dash S. Study of lupus anticoagulant in pregnant women with recurrent abortion. Aust N Z J Obstet Gynaecol 1991;31(4):323-326.

41. Asherson RA, Cervera R. 'Primary', 'secondary' and other variants of the antiphospholipid syndrome. Lupus 1994;3(4):293-298.

42. Ogasawara M, Aoki K, Matsuura E, Sasa H, Yagami Y. Anti beta 2glycoprotein I antibodies and lupus anticoagulant in patients with recurrent pregnancy loss: prevalence and clinical significance. Lupus 1996;5(6):587592.

43. De Carolis S, Caruso A, Ferrazzani S, Carducci B, De Santis L, Mancuso S. Poor pregnancy outcome and anticardiolipin antibodies. Fetal Diagn Ther 1994;9(5):296299.

44. Blumenfeld Z, Weiner Z, Lorber M, Sujov P, Thaler I. 
Anticardiolipin antibodies in patients with recurrent pregnancy wastage: treatment and uterine blood flow. Obstet Gynecol 1991;78(4):584-589.

45. Brown HL. Antiphospholipid antibodies and recurrent pregnancy loss. Clin Obstet Gynecol 1991;34(1):17-26.

46. Carmo-Pereira S, Bertolaccini ML, Escudero-Contreras A, Khamashta MA, Hughes GR. Value of IgA anticardiolipin and anti-beta2-glycoprotein I antibody testing in patients with pregnancy morbidity. Ann Rheum Dis 2003;62(6):540-543.

47. Nishiguchi T, Kobayashi T. Antiphospholipid syndrome: characteristics and obstetrical management. Curr Drug Targets 2005;6(5):593-605.

48. Zammiti W, Mtiraoui N, Kallel C, Mercier E, Almawi WY, Mahjoub T. A case-control study on the association of idiopathic recurrent pregnancy loss with autoantibodies against beta2-glycoprotein I and annexin V. Reproduction 2006;131(4):817-822.

49. Wilson WA, Gharavi AE, Koike T, Lockshin MD, Branch DW, Piette JC, Brey R, et al. International consensus statement on preliminary classification criteria for definite antiphospholipid syndrome: report of an international workshop. Arthritis Rheum 1999;42(7):13091311.

50. Miyakis S, Lockshin MD, Atsumi T, Branch DW, Brey RL, Cervera R, Derksen RH, et al. International consensus statement on an update of the classification criteria for definite antiphospholipid syndrome (APS). J Thromb
Haemost 2006;4(2):295-306.

51. Jones DW, MacKie IJ, Gallimore MJ, Winter M. Antibodies to factor XII and recurrent fetal loss in patients with the anti-phospholipid syndrome. Br J Haematol 2001;113(2):550-552.

52. D’Uva M, Strina I, Mollo A, Ranieri A, De Placido G, Di Micco P. Acquired factor XII deficiency in a woman with recurrent pregnancy loss: working on a differential diagnosis in a single case. J Transl Med 2005;3(43.

53. Dossenbach-Glaninger A, van Trotsenburg M, Krugluger W, Dossenbach MR, Oberkanins C, Huber J, Hopmeier P. Elevated coagulation factor VIII and the risk for recurrent early pregnancy loss. Thromb Haemost 2004;91(4):694-699.

54. Tal J, Schliamser LM, Leibovitz Z, Ohel G, Attias D. A possible role for activated protein $\mathrm{C}$ resistance in patients with first and second trimester pregnancy failure. Hum Reprod 1999;14(6):1624-1627.

55. Gris JC, Quere I, Monpeyroux F, Mercier E, RipartNeveu S, Tailland ML, Hoffet M, et al. Case-control study of the frequency of thrombophilic disorders in couples with late foetal loss and no thrombotic antecedent--the Nimes Obstetricians and Haematologists Study5 (NOHA5). Thromb Haemost 1999;81(6):891899.

56. Marquard K, Westphal LM, Milki AA, Lathi RB. Etiology of recurrent pregnancy loss in women over the age of 35 years. Fertil Steril 2009. 